\title{
GROWTH OF HETEROTROPHIC BACTERIA IN SEA WATER POLLUTED BY RINSO DETERGENT
}

\author{
Cahyani Fitrah Tanjung, Irwan Effendi, Elizal* \\ ${ }^{1}$ Faculty of Fisheries and Marine University of Riau, Pekanbaru \\ *elizal_faperika@yahoo.co.id
}

\begin{abstract}
This research was conducted in March-April 2017 at Marine Microbiology Laboratory, Faculty of Fisheries and Marine University of Riau. The purpose of this study is to determine the different concentration of detergent $(0 \mathrm{ml} / \mathrm{L}, 1.5 \mathrm{ml} / \mathrm{L}, 3 \mathrm{ml} / \mathrm{L}, 4.5 \mathrm{ml} / \mathrm{L}, 6 \mathrm{ml} / \mathrm{L})$ in different observation time $(0,5,10,15,20)$ on the growth of heterotrophic bacteria in sea water. Completely randomized design was used in this experimental method. The results showed that bacterial growth of all treated samples decreased on the 5th day of incubation. However, the population began to increase on the 10th day of incubation. The count of maximum bacterial growth was $1.46 \times 109$ found in the $4.5 \mathrm{ml} / \mathrm{L}$ treated detergent, and the lowest growth was $3.73 \times 107$ in the $1.5 \mathrm{ml} / \mathrm{L}$ treated detergent. Statistical analysis (ANOVA) showed that the concentrations in different observation times on the growth of heterotrophic bacteria showed significant effect and the value was $(\mathrm{P}<0.005)$.
\end{abstract}

Keywords: heterotrophic bacteria, population growth, rinso, sea water.

\section{PENDAHULUAN}

Pencemaran laut diartikan sebagai adanya kotoran atau hasil buangan aktivitas makhluk hidup yang masuk ke daerah laut. Ekosistem laut merupakan ekosistem paling banyak disebut dalam pencemaran lingkungan laut karena merupakan muara atau akhir dari perjalanan suatu zat pencemar yang masuk ke alam. Sumber dari pencemaran laut ini antara lain adalah tumpahan minyak, sisa damparan amunisi perang, buangan proses di kapal, buangan industri ke laut, proses pengeboran minyak di laut, buangan sampah dari darat melalui sungai, emisi transportasi laut dan buangan pestisida di perairan (Ali, 2016).

Aktivitas-aktivitas manusia yang berlokasi di daerah aliran sungai dan wilayah muara baik langsung maupun tidak langsung berpotensi mencemari lingkungan perairan. Laut yang luas diperkirakan akan mampu menghancurkan dan melarutkan bahan-bahan yang dibuang ke perairan laut. Namun laut sebagai sistem mempunyai kemampuan daya urai yang terbatas, selain itu terdapat beberapa bahan yang sulit terurai hal ini akan berakibat pada sulit terdegradasinya limbah dan akhirnya terakumulasi di alam (Susana dan Rositasari, 2009).

Dari sekian banyak limbah, deterjen merupakan limbah pemukiman yang paling potensial mencemari perairan. Penggunaan deterjen sebagai bahan pembersih dalam kehidupan sehari-hari semakin meningkat setiap tahunnya seiring dengan pertambahan jumlah penduduk. Deterjen merupakan bahan aktif permukaan (surfaktan) yang memiliki bagian komponen polar dan nonpolar dalam molekulnya. Masalah yang ditimbulkan akibat pemakaian deterjen terletak pada pemakaian jenis surfaktan dan gugus pembentuk. Akibat Surfaktan di dalam air, sisa deterjen harus mampu mengalami degradasi (penguraian) oleh bakteri-bakteri yang umumnya terdapat di alam. Lambatnya proses degradasi ini mengakibatkan timbulnya busa di atas permukaan air, dalam jumlah yang makin lama makin banyak. Hal ini disebabkan oleh bentuk struktur surfaktan yang dipakai. Jika struktur kimia berupa rantai 
lurus, gugus surfaktan ini mudah diuraikan. Sedangkan jika struktur berupa rantai bercabang, maka surfaktan ini sulit dipecahkan.

Menurut Suastuti et al., (2015) selain NaDBS dan STPP, pencemaran deterjen di perairan juga disebabkan oleh adanya kandungan surfaktan dalam deterjen seperti alkil benzene sulfonat (ABS) dan linear alkil sulfonat (LAS). Surfaktan yang terakumulasi di perairan akan mengakibatkan difusi oksigen dari udara berlangsung lambat, sehingga oksigen yang terlarut dalam air menjadi sedikit.

Menurut Prahastuti dalam Rubiatadji (2013) salah satu jenis deterjen yang banyak digunakan di rumah tangga sebagai bahan pencuci pakaian adalah deterjen merek rinso anti noda. Rinso diluncurkan sebagai merek deterjen pertama di negara ini. Akan tetapi, sebenarnya ini adalah merek yang paling lazim digunakan di Amerika Serikat, Inggris dan Australia sejak tahun 1918. Deterjen jenis ini mengandung ABS (alkil benzene sulfonat) yang merupakan deterjen tergolong keras. Deterjen tersebut sukar dirusak oleh mikroorganisme (nonbiodegradable) sehingga dapat menimbulkan pencemaran lingkungan.

Di samping itu masalah yang ditimbulkan oleh gugus pembentuk yaitu gugus ini akan mengalami hidrolisis yang menghasilkan ion ortofosfat. Gugus ini sangat berpengaruh dalam proses eutrofikasi, yang bisa mengakibatkan tanaman alga dan tanaman air tumbuh secara liar. Surfaktan ini dapat mencemari lingkungan seperti dapat menurunkan kadar oksigen air sehingga organisme air kekurangan oksigen dan dapat menyebabkan kematian (Lichtenberg et al., 2013).

Kerugian lain karena proses eutrofikasi di perairan adalah menyebabkan pendangkalan sungai. Sebaliknya deterjen dengan rendah fosfat beresiko menyebabkan iritasi pada tangan dan kaustik karena lebih bersifat alkalis, dimana tingkat keasamannya antara 10 12 (Setyobudiarso, 2014).

Bakteri yang mampu menguraikan senyawa deterjen adalah bakteri yang memanfaatkan senyawa tersebut menjadi sumber nutrien, sehingga hasil deterjen yang telah terdegradasi oleh bakteri, tidak menjadi polutan yang menghasilkan toksik berbahaya bagi kehidupan organisme di perairan laut. Namun terlalu banyaknya limbah deterjen yang masuk ke perairan menyebabkan susah bagi bakteri dalam menguraikan senyawa deterjen dan membutuhkan waktu yang lama dalam proses degradasinya sehingga hanya beberapa jenis bakteri yang mampu menguraikan deterjen.

Penelitian ini bertujuan untuk mengetahui pengaruh pemberian konsentrasi deterjen jenis rinso dengan dosis yang berbeda dan waktu pengamatan yang berbeda terhadap pertumbuhan bakteri heterotrofik pada air laut. Adapun manfaat dari penelitian ini adalah memberikan informasi mengenai pengaruh deterjen jenis rinso terhadap penghambatan pertumbuhan bakteri heterotrofik di perairan.

\section{METODE PENELITIAN}

Penelitian ini dilaksanakan pada bulan Maret sampai bulan April 2017 di Laboratorium Mikrobiologi Laut Fakultas Perikanan dan Kelautan Universitas Riau. Pengambilan sampel air laut dilakukan pada perairan Desa Kayu Ara, Kabupaten siak (Lampiran 1).

Metode penelitian yang digunakan yaitu metode eksperimen dengan Rancangan Acak Kelompok Faktor (RAKF) dua faktorial terdiri dari 5 taraf perlakuan kadar deterjen yang berbeda dan tiga kali ulangan. Dimana faktor A adalah konsentrasi deterjen rinso yang terdiri dari 5 taraf, yaitu $0 \%$ (R0), 0,3\% (R1), 0,6\% 
(R2), $0,9 \quad \% \quad(\mathrm{R} 3)$ dan $1,2 \quad \% \quad$ (R4). Sedangkan Faktor B adalah waktu pengamatan yaitu 0 hari, 5 hari, 10 hari, 15 hari dan 20 hari. Penghitungan jumlah bakteri dilakukan dengan metoda tuang tebar (spreader plate method).

Pengambilan sampel air laut dilakukan pada bagian permukaan perairan Desa Kayu Ara, Kabupaten Siak, dimana kondisi perairan ini berada dekat dengan daerah hutan mangrove. Kawasan hutan mangrove merupakan daerah kelimpahan bakteri heterotrofik yang paling tinggi, hal ini sesuai dengan penelitian Damar (2013) yang menunjukkan bahwa daerah perairan yang dekat dengan hutan mangrove merupakan kawasan melimpahnya klorofila, hasil analisis regresi dengan scatterplot yang dilakukan yaitu konsentasi klorofil-a berkorelasi positif dengan kelimpahan bakteri heterotrofik. Sehingga kelimpahan klorofil- a juga menyebabkan kelimpahan pada bakteri heterotrofik.

Sampel air laut diambil pada waktu siang hari karena menurut Maryam (2010) aktifitas mikroorganisme pendekomposisi bahan organik cenderung lebih tinggi pada siang hingga sore hari. Air laut diambil menggunakan jeregen volume 5 liter yang sebelumnya sudah disterilkan. Sampel air laut diambil sebanyak 15 liter lalu disimpan dalam ice box untuk menjaga agar sampel air laut tetap berada dalam kondisi mikrobiologis yang sebenarnya selama perjalanan ke Laboratorium Mikrobiologi Laut.

Data yang diperoleh dari hasil penelitian akan disajikan dalam bentuk tabel dan grafik. Untuk melihat perbedaan pengaruh masing-masih perlakuan terhadap pertumbuhan bakteri heterotrofik digunakan uji ANOVA dengan prinsip rancangan acak kelompok faktorial (Gaspersz, 1994). Jika perlakuan berbeda nyata maka dilanjutkan dengan uji lanjut menggunakan uji BNT.

\section{HASIL DAN PEMBAHASAN}

Dari hasil perhitungan bakteri selama 20 hari dengan selang waktu 5 hari pada tiga kali pengulangan, nilai rata-ratayang dihasilkan dari perhitungan bakteri dapat dilihat pada Tabel 4.

Tabel 4. Jumlah rata-rata pertumbuhan bakteri heterotrofik pada kadar konsentasi yang berbeda selama 20 hari

\begin{tabular}{lccccc}
\hline \multirow{2}{*}{$\begin{array}{l}\text { Jumlah sel bakteri } \\
\text { (sel/ml) }\end{array}$} & 0 & 5 & 10 & 15 & 20 \\
\cline { 2 - 6 } $\mathrm{R} 1(0 \mathrm{ml} / \mathrm{L})$ & $1,79 \times 10^{8}$ & $1,43 \times 10^{8}$ & $1,79 \times 10^{9}$ & $1,83 \times 10^{9}$ & $1,05 \times 10^{9}$ \\
$\mathrm{R} 2(3 \mathrm{ml} / \mathrm{L})$ & $1,22 \times 10^{8}$ & $3,73 \times 10^{7}$ & $1,29 \times 10^{9}$ & $9,00 \times 10^{8}$ & $5,71 \times 10^{8}$ \\
$\mathrm{R} 3(6 \mathrm{ml} / \mathrm{L})$ & $1,11 \times 10^{8}$ & $4,48 \times 10^{7}$ & $1,32 \times 10^{9}$ & $1,01 \times 10^{9}$ & $7,89 \times 10^{8}$ \\
$\mathrm{R} 4(9 \mathrm{ml} / \mathrm{L})$ & $1,65 \times 10^{8}$ & $5,08 \times 10^{7}$ & $1,40 \times 10^{9}$ & $1,20 \times 10^{9}$ & $1,01 \times 10^{9}$ \\
$\mathrm{R} 5(12 \mathrm{ml} / \mathrm{L})$ & $1,18 \times 10^{8}$ & $5,77 \times 10^{7}$ & $1,46 \times 10^{9}$ & $1,25 \times 10^{9}$ & $1,13 \times 10^{9}$ \\
\hline
\end{tabular}

Berdasarkan tabel 4 dapat dilihat bahwa pertumbuhan bakteri heterotrofik pada selang waktu inkubasi $0,5,10,15$ dan 20 hari dengan kadar pemberian deterjen yang berbeda sebagi perlakuan mengalami penurunan pada hari ke 5 inkubasi, namun selanjutnya bakteri mengalami peningkatan pada hari ke 10 inkubasi. Pada semua perlakuan konsentrasi, pertumbuhan bakteri mengalami peningkatan pada hari ke 10 , pada hari ke 15 jumlah bakteri mengalami penurunan tetapi tidak terlalu signifikan, kemudian semakin menurun pada hari ke 20. Untuk lebih jelasnya pertumbuhan bakteri heterotrofik dapat dilihat pada pada Gambar 1. 


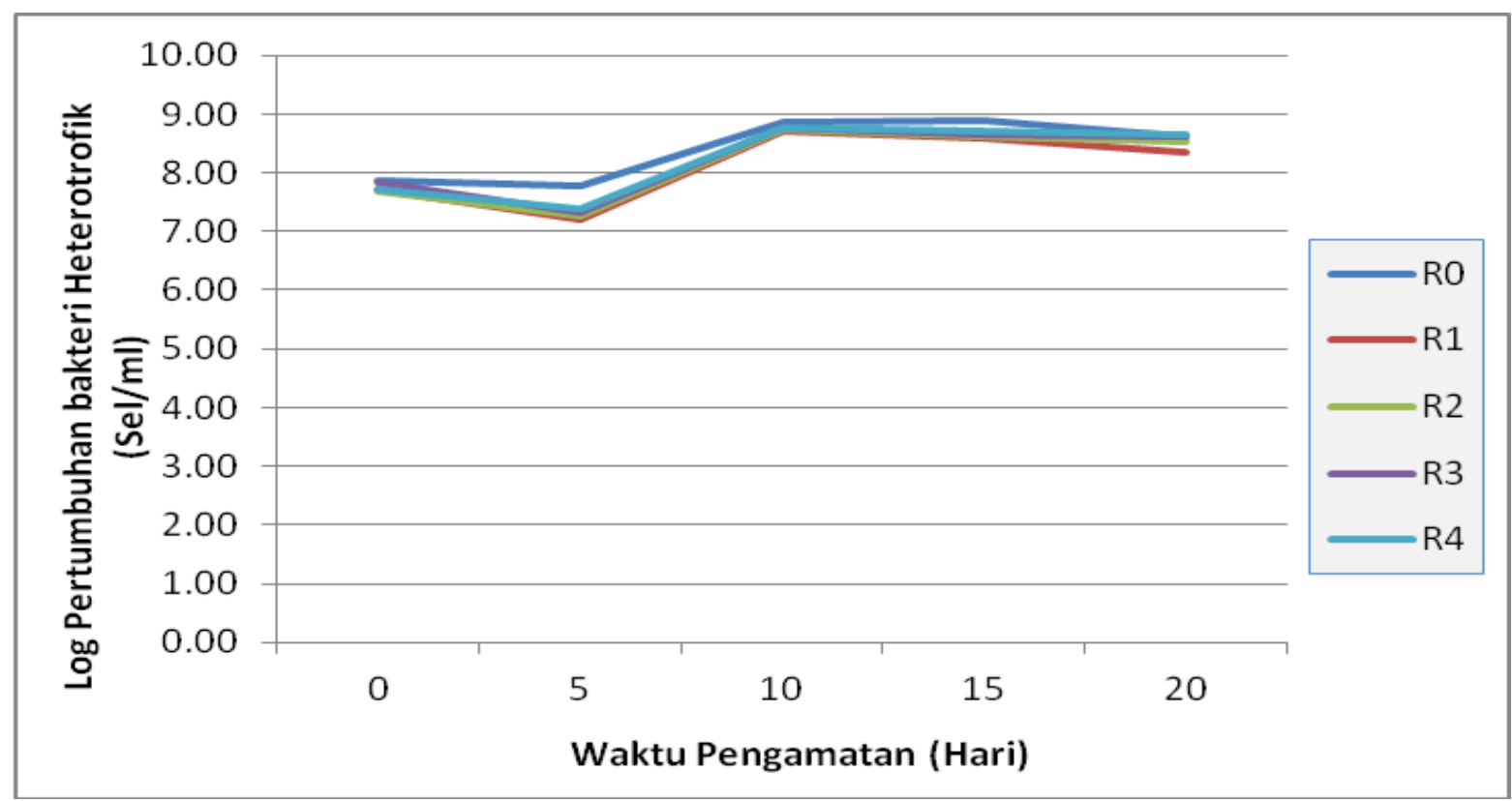

Gambar 1. Grafik Logaritma Pertumbuhan Bakeri Heterotrofik selama 20 hari pada semua perlakuan

Sementara untuk perlakuan (R1), (R2), (R3), (R4) kecuali pada kontrol $\mathrm{R}(0)$, jumlah bakteri mengalami penurunan ada pada perlakuan R1, kemudian mengalami peningkatan pada perlakuan R2, lalu meningkat pada perlakuan R3 sampai pada perlakuan R4 jumlah bakteri semakin meningkat. Untuk lebih jelasnya pertumbuhan bakteri heterotrofik dapat dilihat pada pada Gambar 2.

Jumlah bakteri heterotrofik pada perlakuan R1, awal pemberian deterjen lebih rendah dibandingkan perlakuan R0. Selain R0 (kontrol) jumlah bakteri tertinggi ada pada perlakuan R4, diikuti R3, kemudian R2 dan terendah pada R1. Hal ini menunjukkan bahwa jelas adanya pengaruh penambahan deterjen rinso dalam mikrokosom yang berisi air laut.

Dari semua perlakuan, jumlah bakteri pada hari ke 5 inkubasi mengalami penurunan. Menurunnya jumlah bakteri hari ke 5 pada R0 (kontrol) kemungkinan disebabkan karena sudah adanya pengurangan nutrien yang tersedia bagi pertumbuhan bakteri. Ini disebabkan oleh metabolit bakteri dan zat kimia yang dikeluarkan oleh bakteri itu sendiri. Sedangkan penyebab penurunan jumlah bakteri pada perlakuan lainnya di hari ke 5 inkubasi disebabkan karena adanya senyawa kimia yang bersifat racun bagi mikroorganisme itu sendiri.

Penurunan bakteri juga terjadi karena bakteri tersebut tidak mampu beradaptasi dengan lingkungannya, dan bakteri yang mampu beradaptasilah yang akan terus hidup meskipun ada penambahan deterjen. Menurut Mulyadi (2001) jenis kandungan anionik pada deterjen kadang ditambah juga dengan jenis kationik yang mana berfungsi sebagai bakterisida (pembunuh bakteri).

Sementara menurut Rismana (2004) mendefenisikan disinfektan sebagi bahan kimia yang digunakan untuk membunuh 
atau menurunkan jumlah mikroorganisme. Deterjen merupakan suatu disinfektan bagi bakteri yang menyebabkan ketegangan permukaan sehingga menyebabkan hancurnya bakteri.

Terjadinya penurunan dapat disebabkan kerena bakteri memasuki fase adaptasi, dimana bakteri umumnya selalu menyesuaikan diri terhadap lingkungan baru seperti pada mikrokosom yang mengandung deterjen rinso.

Penurunan persentasi pertumbuhan yang terjadi pada saat penelitian disebabkan karena aktivitas dari bakteri pengurai, dimana bakteri mampu menguraikan gugus rantai deterjen menjadi senyawa yang lebih sederhana. Penurunan persentasi pertumbuhan pada bakteri ini juga diduga ada kaitannya dengan kadar deterjen yang semakin menurun.

Menurut Dwidjoseputro (2003) jasad renik yang dipindahkan ke dalam suatu medium, mula-mula akan mengalami fase adaptasi untuk menyesuaikan dengan substrat dan kondisi lingkungan di sekitarnya. Pertumbuhan bakteri yang mengalami penurunan diduga karena sumber bahan makanan yang berasal dari komposisi deterjen berkurang, dan sudah dimanfaatkan oleh bakteri. Bakteri saling berkompetisi untuk memperoleh makanan, sehingga bakteri yang bisa hidup adalah yang mampu bersaing.

Pada semua perlakuan, hari ke 10 jumlah bakteri mengalami peningkatan, ini kemungkinan terjadi karena adanya populasi bakteri tertentu yang sudah mampu beradaptasi terhadap deterjen. Memurut Waluyo (2004) pada fase logaritmik, bakteri melakukan pembelahan sel dengan sangat cepat sehingga jumlah pertumbuhannya mengikuti kurva logaritmik dan bakteri semakin membutuhkan energi yang lebih banyak. Pertumbuhan bakteri mengalami peningkatan kemungkinan karena adanya bakteri yang sudah mampu memanfaatkan komposisi yang dkandung deterjen sebagai sumber energi untuk berkembang biak.

Menurut (Harijati, 1994) bahwa dalam waktu 11 hari bakteri tertentu mampu menurunkan kadar deterjen sebanyak $0,10 \%$ hal tersebut diduga karena bakteri tersebut sudah menggunakan komposisi deterjen dalam bahan makanannya dan adanya pelepasan gugus sulfonat yang kemudian teroksidasi menjadi sulfat. Selain jenis bakteri kadar surfaktan pada deterjen juga mempengaruhi kecepatan dan penguraian. Deterjen dengan kadar surfaktan jenis ABS yang lebih tinggi akan lebih lama terurai dibangkan dengan kadar LAS yang lebih rendah.

Dari semua perlakuan yang dilakukan, dengan penambahan deterjen terlihat bahwa setelah hari ke 10 inkubasi, semakin hari jumlah bakteri mengalami penurunan. Pada hari ke 15 inkubasi, pertumbuhan bakteri malah mengalami penurunan tetapi tidak begitu signifikan, disini kemungkinan bakteri mengalami fase stasioner, dimana menurut Waluyo (2004) fase stasioner adalah adanya pembelahan sel yang tidak stabil sehingga bakteri mulai mengalami penurunan namun tidak begitu banyak.

Jumlah bakteri heterotrofik semakin terlihat penurunannya pada hari ke 20 . Hal ini disebabkan karena setelah bakteri melewati fase adaptasi, fase logaritmik dan fase stasioner, bakteri mengalami fase ke mengarah kematian. Fase ini terjadi karena jumlah sel yang tumbuh sama dengan jumlah sel mati dan terjadinya populasi bakteri mulai mengalami kematian.

Menurut Wigyanto (1997) Bakteri menggunakan komposisi kimia sebagai bahan makanan dan hasil dari pemanfaatannya adalah turunnya konsentasi. Salah satu mikroorganisme mempunyai sistem genetik yang mampu mensintesis enzim sehingga dapat beradaptasi dan mendegradasi surfaktan deterjen alkil benzene sulfanat. Dalam menguraikan deterjen, bakteri melakukan 
pemutusan di rantai alkil pada gugus fungsi.

Penurunan konsentrasi deterjen dapat dikatakan dipengaruhi oleh jumlah dan jenis bakteri yang ada diperairan. Mengingat bahwa bakteri heterotrofik berperan sebagai salah satu organisme yang mampu mendegradasi lingkungan, maka keberadaan bakteri didalam perairan memberikan pengaruh yang besar dalam menjaga lingkungan perairan, ditambah jumlah bakteri yang cukup banyak di perairan.

Dari hasil uji ANOVA dapat dilihat bahwa interaksi antara kadar deterjen yang berbeda dan waktu pengamatan memberikan pengaruh sangat nyata terhadap pertumbuhan bakteri heterotrofik, dimana nilai $\mathrm{P}<0,05$ (H1 diterima) (Lampiran 4). Uji lanjut (Lampiran 5) yang dilakukan dapat dilihat bahwa perlakuan R3 tidak berbeda nyata dengan perlakuan $\mathrm{R} 4$ tetapi berbeda nyata terhadap perlakuan lainnya.

\section{KESIMPULAN DAN SARAN}

Hasil penelitian pada pemberian konsentrasi deterjen jenis rinso yang berbeda dan waktu pengamatan yang berbeda terhadap pertumbuhan bakteri heterotrofik didapat ada pengaruh yang nyata, dimana nilai $\mathrm{P}<0,005(\mathrm{H} 1$ diterimah). Pertumbuhan bakteri heterotrofik paling tinggi ada pada perlakuan R4 dan terendah pada R1, kemudian berdasarkan hari inkubasi jumlah bakteri semakin mengalami penurunan pada hari ke 15 sampai ke hari 20. Jumlah bakteri mengalami peningkatan pada hari ke 10 inkubasi. Hal ini menunjukkan bahwa penambahan kadar deterjen pada setiap perlakuan mampu menekan pertumbuhan populasi bakteri heterotrofik didalam air laut, terutama pada awal pemberian deterjen.

Penurunan jumlah bakteri heterotrofik sangat dipengaruhi oleh konsentrasi deterjen, dan semakin bertambahnya waktu pengamatan yang dilakukan.

Diharapkan perlu adanya penelitian lanjutan mengenai jenis bakteri apa saja yang mampu dalam menguraikan deterjen tersebut. Selain itu perlu dilakukan pengukuran kadar deterjen agar terlihat berapa jumlah penurunan konsentrasi dalam suatu deterjen dari hari pertama sampai penelitian berakhir sehingga dapat diketahui deterjen mana yang paling mudah untuk diuraikan oleh bakteri heterotrofik tersebut.

\section{DAFTAR PUSTAKA}

1. Achmad, R. 2004. Kimia Lingkungan. Yogyakarta: Penerbit Andi.

2. Ali, F. 2016. Pemanfaatan Limbah Lateks Karet Alam dan Eceng Gondok Sebagai Adsorben Crude Oil. Jurnal Kimia, 22(1): 1-8.

3. [APHA] American Public Health Association. 2005. Standard Methods For the Examination of Water and Wastewater. Amer. Publ. 17th Edition. New York Health Association.

4. Dabelstein, W., A. Reglitzky, A. Schutze, and Reders, K. 2002. Automotive Fuels in Ullmann's Encyclopedia of Industrial Chemistry. Wiley-VCH.

5. Damar, A. 2013. Deteksi Faktor Lingkungan Pemicu Timbulnya Peledakan Populasi Fitoplankton di Perairan Teluk Jakarta dan Kaitannya dengan Eutrofikasi Perairan Pesisir dan Laut dalam Perspektif Perubahan Iklim Global. Laporan Penelitian Unggulan Lembaga Penelitian dan Pengabdian kepada Masyarakat - Institut Pertanian Bogor (LPPM-IPB). Bogor.

6. Dwidjoseputro, D. 2003. Dasar-dasar MIkrobiologi. Penerbit Djambatan. Jakarta. 214. 
7. Effendi, I. 1999. Ekologi Mikroba. Lancang kuning press. Pekanbaru. 145.

8. Fardiaz, S. 1992. Mikirobiologi Pangan. Gramedia Pustaka Utama. Jakarta.

9. Harijati, N., Suharjono dan T.H. Kurniati.1994. Potensi Komunitas Bakteri

10. Pemecah Deterjen Jenis Alkil Bensen Sulfonat (ABS) dan Linier Alkil Benzen Sulfonat (LAS). Jurnal Universitas Brawijaya 6(2). Lembaga Penelitian Universitas Brawijaya. Malang.

11. Hasmi, N. 2016. Analisis Residu Detergen Anionik Linear Alkylbenzene Sulfonate (Las) di Perairan Teluk Kendari Sulawesi Tenggara. Skripsi Fakultas Matematika dan Ilmu Pengentahuan Alam Universitas Halu Oleo, Kendari.

12. Heryani, A dan Puji, H. 2008. Pengolahan Limbah Deterjen Sintentik dengan Trickling Filter. Makalah penelitian. Semarang.

13. Hutabarat. D dan S.M. Evans. 2008. Pengantar Oseonografi. Penerbit Universitas Indonesia.

14. Kamiswari, R., M. T. Hidayat dan Rahayu, Y. S. 2013. Pengaruh Pemberian Deterjen terhadap Motalitas ikan Platy sp. Jurnal Biologi, 2(1): 139-142.

15. Keputusan Menteri Negara Lingkungan Hidup Nomor : 51 Tahun 2004 Tentang Baku Mutu Air Laut (Link: http://www.menlh.go.id), tanggal akses 28 April 2017.

16. Lichtenberg, D., H. Ahyayauch, dan Goni, F. M. 2013. The mechanism of deterjen solubilization of lipid bilayers. Biophysical Journal.

17. Madigan, M. T., D. P. Clarck, John and Martinko, M.. 2011. Brock Microbiology of microorganisms. San Francisco: Benjamin Cummings publishing.

18. Maryam, S.2010. Budidaya Super Intensif Ikan Nila Merah dengan Tehnologi Bioflock: Profil Kualitas Air. Kelangsungan Hidup dan Pertumbuhan. Skripsi. Imstitut Pertanian Bogor.

19. Mulyadi, A. 2011. Gunakan Deterjen Seminimal mungkin. Kompas Edisi Senin. Jakarta.

20. Notowinarto, dan F. Agustina 2015. Populasi Bakteri Heterotrof di perairan Pulau Bulang Batam (Jurnal Pendidikan Biologi Indonesia) Vol . 1(3) Hal. 334 - 342

21. Prahastuti dan Maulina, S. 2013. Dampak Surfaktan Berbahan Aktif Na-ABS Terhadap Daya Tetas Telur Ikan Karper (Cyprinus Carpio) dalam Skala Laboratorium. Journal of Maquares, 2(4): 11-17.

22. Rahma, E. 2005. Populasi Bakteri Heterotrofik Pada Air laut tercemar Sampo. Skripsi. Fakultas Perikanan dan Ilmu Kelautan Universitas Riau. Pekanbaru. 10-11.

23. Rismana, E. 2004. Mengenal Bahan Kimia Desinfeksi. Http://pikiranrakyat.com/cetak/1004/07/cakrawala/lain01.htm. [01 Maret 2017].

24. Sastrawijaya, A. 2000. Pencemaran Lingkungan. Rineka Cipta. Jakarta. 274.

25. Sajiah, L. 2003. Pengaruh Surfaktan detergen Linear Alkylbenzena Sulfonate (LAS) Terhadap Perkembangan Stadia Larva sampai dengan Juvenil Ikan Mas. Skripsi tidak dipublikasikan. Bogor: Departemen Budidaya Perairan. Fakultas Perikanan dan Ilmu Kelautan. Institut Pertanian Bogor.

26. Selanno, D.A.J., J. Natan., Pr.A.Uneputty dan Y.A. Lewerissa. 2013. Analisis Beberapa Parameter Kualitas Air di Daerah Habitat Teripang. Jurnal TRITON 9(1): 1-10.

27. Setyobudiarso, H dan Endro, Y. 2014. Rancang Bangun Alat Penjernih Air Limbah Cair Laundry dengan menggunakan Media Penyaring Kombinasi Pasir-Arang Aktif. Jurnal Lingkungan, 6(2): 1-7. 
28. Smulders, E. W. Rybinski, E. Sung, W. Rahse, J. Steber, F. Wiebel, A. Nordskog. 2002. Laundry Deterjents in Ullmann's Encyclopedia of Industrial Chemistry. Wiley$\mathrm{VCH}$, Weinheim.

29. Suastuti, D. A. I. Wayan. S, Dwi. K, Putra. 2015. Pengelolaan Larutan Diterjen dengan Biofilter Tanaman Kangkungan (Ipomoea Crassicaulis) dalam Sistem Batch (curah) Teraerasi. Jurnal Kimia, 9(1): 98-104.

30. Supriharyono. 2009. Konservasi Ekosistem Sumberdaya hayati di Wilayah Pesisir dan Laut Tropis. Pustaka pelajar, Jogjakarta.

31. 2002. Pelestarian dan Pengelolaan Sumber Daya Alam di Wilayah Pesisir Tropis. Gramedia Pustaka Utama, Jakarta.

32. Susana, T. dan Rositasari, R. 2009. Dampak Deterjen terhadap Foraminifera di Kepulauan Seribu Bagian Selatan, Teluk Jakarta. Oseanologi dan Limnologi di Indonesia, 35 (3): 335-352.

33. Syahfitri, H. 2005. Pertumbuhan Bakteri Heterotrofik pada Air Laut tercemar Deterjen. Skripsi Fakultas Perikanan dan Ilmu kelautan Universitas Riau. Pekanbaru. 37. Waluyo,L. 2004. Mikrobiologi Umum. Universitas Muhammadiyah Malang Press. Malang. 341.

34. Whitten, D. O. and B. E, Whitten. 1997. Handbook of American Business History: Extractives, manufacturing, and services. Greenwood Publishing Group.

35. Wignyanto, S. 1997. Teknik Baru Cara Peningkatan Efektivitas dan Efesiensi kemampuan Biodegradasi Surfaktan Deterjen Alkil Benzene Sulfonate. Jurnal Penelitian ilmu-ilmu teknik. 9(2):7. 